\title{
PEMBERDAYAAN PENGGERAK PKK MELALUI PENGEMBANGAN KERAJINAN SAMPAH NON-ORGANIK DI DESA SANDIK KECAMATAN BATU LAYAR LOMBOK BARAT
}

\author{
Baiq Ismiwati ${ }^{1}$, Taufik Chaidir ${ }^{2}$, Ida Ayu Putri.S ${ }^{3}$, Siti Sriningsih ${ }^{4}$ \\ Fakultas Ekonomi dan Bisnis Universitas Mataram
}

ismiwati2010@gmail.com

\begin{abstract}
ABSTRAK
Bebas sampah adalah tujuan etis, ekonomis, efisien dan visioner, untuk memandu masyarakat dalam mengubah gaya hidup dan praktik-praktik mereka dalam meniru siklus alami yang berkelanjutan, dimana semua material yang tidak terpakai lagi dirancang untuk menjadi sumberdaya bagi pihak lain untuk menggunakannya (id.m.wikipedia.org).

Permasalahan terkait sampah di Desa Sandik yaitu : 1.Sampah non-organik relatif banyak tersebar di lingkungan Desa Sandik; 2. Bank sampah belum beroperasi; 3. Masyarakat belum banyak tahu tentang sampah non-organik yang dapat dijadikan sebagai bahan baku produk-produk kreatif yang memiliki nilai jual; 4. Tim PKK desa Sandik belum memiliki keterampilan mengolah sampah non-organik menjadi produk kerajinan bernilai ekonomis. Tujuan pengabdian adalah untuk memberdayakan Tim Penggerak PKK Desa Sandik dalam pengolahan sampah nonorganik menjadi barang yang memiliki nilai ekonomis. Metode pengabdian dilakukan dengan ceramah, diskusi, dan pelatihan teknis pengolahan sampah nonorganik menjadi produk yang bernilai jual. Hasil kegiatan: terdapat beberapa peserta yang mampu membuat produk diakhir pelatihan; Adanya kesediaan dan antusiasme dari peserta untuk menularkannya kepada ibu-ibu lain di sekitar desa. Dapat disimpulkan bahwa kegiatan pengabdian ini berhasil yang ditunjukkan oleh: Peserta dapat memilah antara sampah organik dan non-organik serta bertambahnya pengetahuan peserta tentang beberapa sampah non-organik yang
\end{abstract}


mereka hasilkan setiap hari dapat dimanfaatkan dan diolah menjadi barang yang bermanfaat dan mempunyai nilai ekonomis.

Kata kunci: Pemberdayaan Penggerak PKK, sampah non-organik, nilai Ekonomis

\begin{abstract}
Zero waste is an ethical, economical, efficient and visionary goal, to guide people in changing their lifestyles and practices in imitation of a sustainable natural cycle, where all materials that are no longer used are designed to be a resource for others to use (en. m.wikipedia.org).

Problems related to waste in Sandik Village are: 1. Non-organic waste is relatively widely scattered in the Sandik Village environment; 2 . The waste bank is not yet operational; 3. People do not know much about non-organic waste which can be used as raw material for creative products that have a selling value; 4. The Sandik Village PKK Team does not have the skills to process non-organic waste into handicraft products with economic value. The aim of this service is to empower the Sandik Village PKK Driving Team in processing non-organic waste into goods that have economic value. The service method is carried out with lectures, discussions, and technical training on processing non-organic waste into products with sale value. The results of the activity: there were several participants who were able to make products at the end of the training; Participants were willing and enthusiastic to pass it on to other mothers around the village. It can be concluded that this service activity was successful, as shown by: Participants were able to sort between organic and non-organic waste and increased participants' knowledge about some of the non-organic waste that they produce every day can be used and processed into useful and economic value items
\end{abstract}

Keywords: Empowerment of PKK Movers, non-organic waste, Economic value 


\section{PENDAHULUAN}

Bebas sampah adalah filsafat yang mendorong perancangan ulang daur sumberdaya dari sistem linier menuju siklus tertutup, sehingga semua produk digunakan kembali. Definisi bebas sampah yang diakui secara internasional, yang digunakan oleh (ZWIA) adalah: "Bebas sampah adalah tujuan etis, ekonomis, efisien dan visioner, untuk memandu masyarakat dalam mengubah gaya hidup dan praktek-praktek mereka dalam meniru siklus alami yang berkelanjutan, dimana semua material yang tidak terpakai lagi dirancang untuk menjadi sumberdaya bagi pihak lain untuk menggunakannya (id.m.wikipedia.org).

Dalam wikipedia juga dikatakan : Bebas sampah berarti merancang dan mengelola produk dan proses untuk secara sistematis menghindari dan menghilangkan jumlah dan daya racun limbah dan material, melestarikan dan memulihkan semua sumberdaya dan tidak membakar dan menguburnya. Jika semua dapat diwujudkan maka lingkungan hidup yang bersih, sehat dan berkelanjutan akan dapat kita nikmati. Berkaitan dengan hal tersebut, peran dan kesadaran mansyarakat untuk selalu menjaga lingkungan disekitarnya sangat diharapkan. Oleh karena itu pendidikan lingkungan hidup sangat diperlukan sehingga kelestarian lingkungan dapat terjaga.

Pendidikan lingkungan hidup (environmental education) adalah suatu proses untuk membangun seluruh umat manusia di dunia sadar dan peduli terhadap lingkungan dan segala masalah yang berkaitan dengannya. Permasalahan tersebut tidak terlepas dari masyarakat yang memiliki pengetahuan, ketrampilan, sikap dan tingkah laku, motivasi serta komitmen untuk bekerja sama untuk dapat memecahkan berbagai masalah lingkungan saat ini dan mencegah timbulnya masalah baru. Pasal 5 Undang Undang Pengelolan Lingkungan Hidup No.23 Th.1997, menyatakan bahwa masyarakat berhak atas Lingkungan hidup yang baik dan sehat. Untuk mendapatkan hak tersebut,pada pasal 6 dinyatakan bahwa masyarakat dan pengusaha berkewajiban untuk berpartisipasi dalam memelihara kelestarian 
fungsi lingkungan, mencegah dan menaggulangi pencemaran dan kerusakan lingkungan.Terkait dengan ketentuan tersebut, dalam UU NO. 18 Tahun 2008 secara eksplisit juga dinyatakan, bahwa setiap orang mempunyai hak dan kewajiban dalam pengelolaan sampah. Dalam hal pengelolaan sampah pasal 12 dinyatakan, setiap orang wajib mengurangi dan menangani sampah dengan cara berwawasan lingkungan. Tidak terkecuali, baik dari perorangan, rumah tangga, dusun, desa, sampai ke tingakat pemerintahan yang lebih atas, dianjurkan untuk dapat menangani sampah, baik sampah organik maupun non organik.

Terkait dengan sampah dan lingkungan hidup, maka pengetahuan tentang pemanfaatan sampah, terutama pemanfaatan sampah non-organik sangat penting diberikan kepada masyarakat, terutama masyarakat desa yang pada umumnya memiliki pengetahuan yang masih rendah tentang kebersihan lingkungan dan kesehatan dan belum bisa memanfaatkan sampah nonorganik menjadi barang yang bernilai ekonomis. Sampah non-organik (seperti botol, gelas plastik bekas minuman kemasan, kulit permen maupun plastik bekas kemasan makanan ringan ataupun kemasan kopi instan) yang tidak bisa cepat diurai dan hancur menyatu dengan tanah dapat mencemarkan lingkungan, tetapi apabila dimanfaatkan dan diolah menjadi barang yang bernilai ekonomis, akan dapat dijadikan sebagai sumber tambahan pendapatan keluarga.

Desa Sandik merupakan salah satu desa di Kecamatan Batulayar Kabupaten lombok Barat dengan Luas wilayah 7,00 km2 dengan jumlah dusun yang ada di desa ini sebanyak 16 dusun. Jumlah penduduk 13.391 jiwa (laki-laki 6.606 jiwa dan perempuan 6.785 jiwa) dengan 3.871KK. Seperti desa-desa lainnya yang ada di Kabupaten Lombok Barat, untuk penanganan sampah, desa telah membentuk Bank sampah yang mencakup semua dusun, sebagai upaya menuju desa yang bebas sampah (Zerro Waste). Akan tetapi sampai saat ini di Desa Sandik bank sampah belum berfungsi. Saat ini yang baru dilakukan adalah warga mengumpulkan botol-botol atau gelas plastik bekas minuman kemasan dan dijual pada satu pengepul yang ada di desa. 
Sama sekali belum ada upaya untuk memanfaatkan dan mengolahnya untuk menjadi barang kerajinan yang bernilai ekonomis.

Seperti kita ketahui, Pemerintahan Desa merupakan ujung tombak pelayanan publik, dikepalai oleh seorang Kepala Desa yang dipilih secara langsung oleh masyarakat Desa. Untuk mendukung keberhasilan pembangunan khususnya di bidang kesejahteraan keluarga, maka di Desa Sandik dibentuk tim penggerak PKK desa yang diketuai oleh istri Kepala Desa. Peranan Tim penggerak PKK sangat strategis, baik sebagai motivator di berbagai bidang, baik dibidang pendidikan, keluarga berencana, kesehatan keluarga, keterampilan keluarga, peningkatan keahlian keluarga masyarakat, juga sebagai wahana pendamping pengembangan ekonomi kereatif, maupun berbagai pengetahuan lainnya terkait kesejahteraan keluarga.

Disamping sebagai motivator, Tim penggerak PKK juga sebagai teladan atau contoh bagi anggota masyarakat (khususnya ibu-ibu) terutama dalam mengembangkan ekonomi kreatif sebagai salah satu cara untuk meningkatkan pendapatan keluarga. Pada saat perempuan mampu bergerak pada sektor ekonomi yang memiliki jiwa wirausaha disertai dengan kemampuan teknik dan pengelolaan usaha tanpa meninggalkan fungsinya dalam keluarga, akan muncul kekuatan ekonomi yang berasal dari potensi perempuan dan pada gilirannya akan berkontribusi pada perekonomian wilayah secara umum.

Peran serta perempuan dalam kegiatan ekonomi didorong oleh berbagai penyebab diantaranya adalah; tuntutan kebutuhan yang semakin banyak, terbatasnya penghasilan suami, tanggungan keluarga relatif banyak, sulitnya mendapatkan pekerjaan di sektor formal, dan lainnya. Selanjutnya sampah sebagai barang yang dipandang tidak berguna (hususnya sampah non-organik) terdapat cukup banyak dilingkungan sekitar, dan bila tidak dikelola secara baik akan menimbulkan dampak pencemaran lingkungan. Namun bagi orang-orang yang kreatif sesungguhnya sampah adalah suatu peluang yang dapat mendatangkan penghasilan (pendapatan).

Ibu-ibu tim penggerak PKK, di Desa Sandik sebagian besar belum paham dalam memanfaatkan peluang ini sebagai salah satu sarana untuk 
mengatasi permasalahan yang dihadapi. Untuk meningkatkan peran ibu-ibu penggerak PKK, dapat melalui peningkatan usaha-usaha ekonomi kreatif yang salah satunya adalah pengelolaan sampah non-organik yang semula tidak bernilai, mengotori lingkungan, menimbulkan bau, mengganggu kesehatan dan lainnya menjadi barang yang berguna dan bernilai ekonomis. Sampah non organik yang dapat di manfaatkan berupa sampah plastik, bungkus snack, sedotan, kaleng, dan lain sejenisnya. Sementara hasil produknya antara lain: tas, topi, taplak meja, lampu hias , piring makan dan lain-lain. Prinsipnya adalah meminimalisasi timbulnya sampah, memanfaatkan, dan mendaur ulang sampah (prinsip 3R - reduce, reuse, recycle). Dengan prinsip ini tentunya akan mendatangkan manfaat ekonomi dan menjadikan lingkungan bersih, yang pada akhirnya menghasilkan outcome yang dapat langsung dirasakan, yaitu kesehatan lingkungan dan peningkatan penghasilan.

Berdasarkan analisis situasi dan permasalahan yang dihadapi oleh para ibuibu di desa Sandik terkait dengan sampah (khususnya sampah non-organik), maka Tim merasa perlu untuk membagi pengetahuan dengan memberdayakan Tim Penggerak PKK Desa di Desa Sandik untuk dapat memanfaatkan sampah non-organik yang terdapat dilingkungan sekitar dengan mengolahnya menjadi produk yang bernilai ekonomis yang nantinya diharapkan dapat dikembangkan dan dapat membantu mereka untuk menambah pendapatan keluarga. Disamping itu manfaat lainnya yang didapat adalah terjaganya lingkungan desa dari pencemaran sampah non-organik. Kegiatan pemberdayaan dilakukan dengan metode ceramah, diskusi, dan pelatihan teknis pengolahan sampah non-organik menjadi produk yang bernilai jual.

\section{METODE KEGIATAN}

Kegiatan pemberdayaan penggerak PKK melalui pengembangan kerajinan sampah non-organik di Desa Sandik Kecamatan Batulayar Kabupaten Lombok Barat, dilakukan dengan dua metode, yakni; (a) metode 


\section{Jurnal ABDIMAS INDEPENDEN}

Vol. 2, No. 2, November 2021

ceramah, diskusi, dan tanya-jawab untuk materi Manajemen usaha, dan (b) metode pelatihan ( praktik) untuk pemanfaatan sampah plastik menjadi produk kreatif bernilai ekonomis. Sementara pendampingan di lakukan selama satu bulan untuk melihat hasil dari pelatihan yang diberikan. Pendampingan ini ditekankan pada upaya penguasaan ekononomi kreatif, dan networking.

Pelatihan dibagi dalam dua tahap yaitu: (1). Materi tentang kebersihan lingkungan dan materi menejemen usaha yang meliputi: Persaratan Mutu Seorang Penjual, Kewirausahaan dan Pembukuan sederhana. (2). Pelatihan keterampilan ekonomi kreatif, yakni pelatihan mengolah sampah plastik menjadi produk bernilai ekonomi. Beberapa pelatihan dasar produk yang dilatih seperti; inke ( piring ), tas, peci, bunga dan lain-lain.

Kegiatan pelatihan dilaksanakan di Aula kantor desa Sandik pada tanggal 11 September 2020. Jumlah peserta yang hadir sebanyak 6 orang dari 15 orang yang direncanakan. Peserta yang menjadi sasaran kegiatan adalah aggota penggerak PKK desa Sandik kecamatan Batu LayarKabupaten Lombok Barat. Dengan harapan nantinya pengetahuan yang mereka dapatkan dapat dibagi atau ditularkan pada ibu-ibu lainnya yang ada di Desa Sandik.

\section{HASIL DAN PEMBAHASAN}

Pada saat penyampaian materi dengan menggunakan ceramah, Tim pengabdian menyampaikan beberapa materi, yakni materi tentang kebersihan lingkungan dan materi menejemen usaha, seperti materi kewirausahaan, persyaratan mutu seorang penjual, pembukuan sederhana, para peserta memperhatikan dengan baik, dan berusaha memahami apa yang disampaikan oleh penyaji. Pada saat penyampaian materi tentang kebersihan lingkungan, disamapaikan bagaimana limbah non-organik dapat mencemarkan tanah dan sulit diurai, sehingga masyarakat juga perlu tahu mana sampah yang termasuk sampah organik dan mana yang non-organik. 
Peserta juga diberikan pengetahuan bahwa ada beberapa jenis sampah nonorganik yang mereka hasilkan setiap harinya dapat dimanfaatkan dan diubah/diolah menjadi sesuatu yang bermanfaat dan dapat mereka jadikan sebagai sumber tambahan pendapatan keluarga. Dari pengetahuan ini para peserta menjadi tahu bahwa sampah non-organik yang mereka hasilkan setiap hari disamping dapat mengurangi pencemaran lingkungan sekitar mereka juga dapat mereka jadikan sebagai sumber tambahan penghasilan keluarga. Penyampaian materi mengenai pengelolaan usaha, dimaksudkan agar produk yang dihasilkan dapat mereka kelola sebagai bisnis dan untuk itu para peserta diberikan pengetahuan dasar tentang persaratan mutu seorang penjual, pembukuan sederhana dan kewirausahaan.

Pelatihan Teknis pembuatan kerajinan dari sampah non-organik dilakukan oleh seorang yang ekspert dibidang kreasi pembuatan kerajinan dari sampah non-organik. Sesi ini dimulai dengan pembelajaran mengenai pemilahan sampah non-organik yang dapat dijadikan sebagai bahan untuk pembuatan aneka kreasi kerajinan. Selanjutnya bagaimana proses membuat dan membentuknya sehingga dapat dianyam menjadi suatu produk kerajinan. Sesi ini adalah merupakan sesi yang paling menarik bagi para peserta. Terlihat dari antusiasme pera peserta dalam mengikuti pelatihan. Suasana pelatihan penuh dengan pertanyaan-pertanyaan dari para peserta saat praktek pembuatan inke dari salah satu bagian dari gelas minuman kemasan ataupun pembuatan bunga dari tas plastik (kresek) dilakukan. Para peserta rata-rata bertanya bagaimana cara membuatnya. Sampai akhirnya mereka dapat membuat/menganyam satu produk dasar yang berasal dari gelas air minum kemasan yang nantinya dapat dibuat menjadi berbagai bentuk produk sesuai keinginan, seperti inke (piring), tas, peci, tempat air minum kemasan, dan lain-lain. Sampai dengan akhir kegiatan rata-rata para peserta sudah dapat menghasilkan sebuah inke (piring). Untuk foto-foto produk dan kegiatan pelatihan dapat dilihat dibawah ini: 


\section{Jurnal ABDIMAS INDEPENDEN}

Vol. 2, No. 2, November 2021

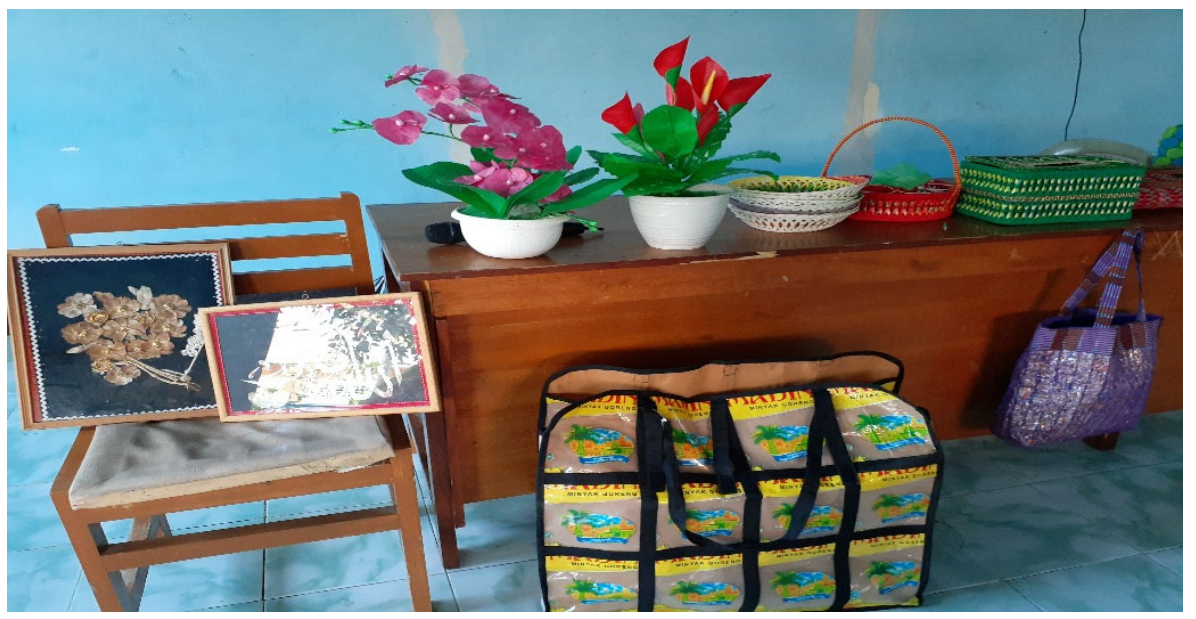

Foto: Hasil produk dari sampah non-organik

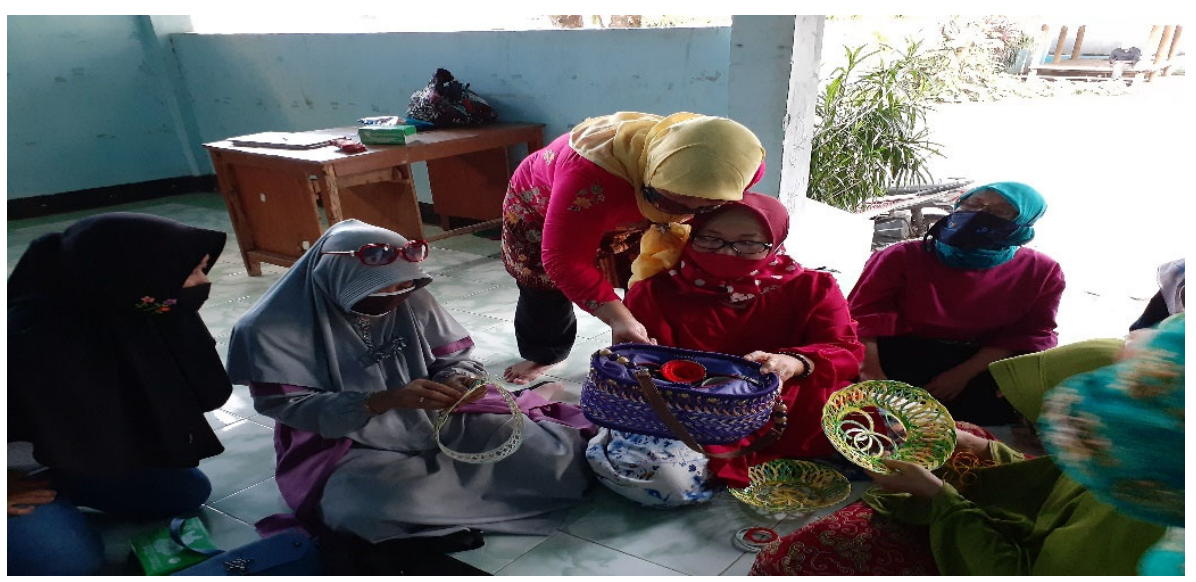

Foto: Saat Pelatihan pembuatan kerajinan berlangsung

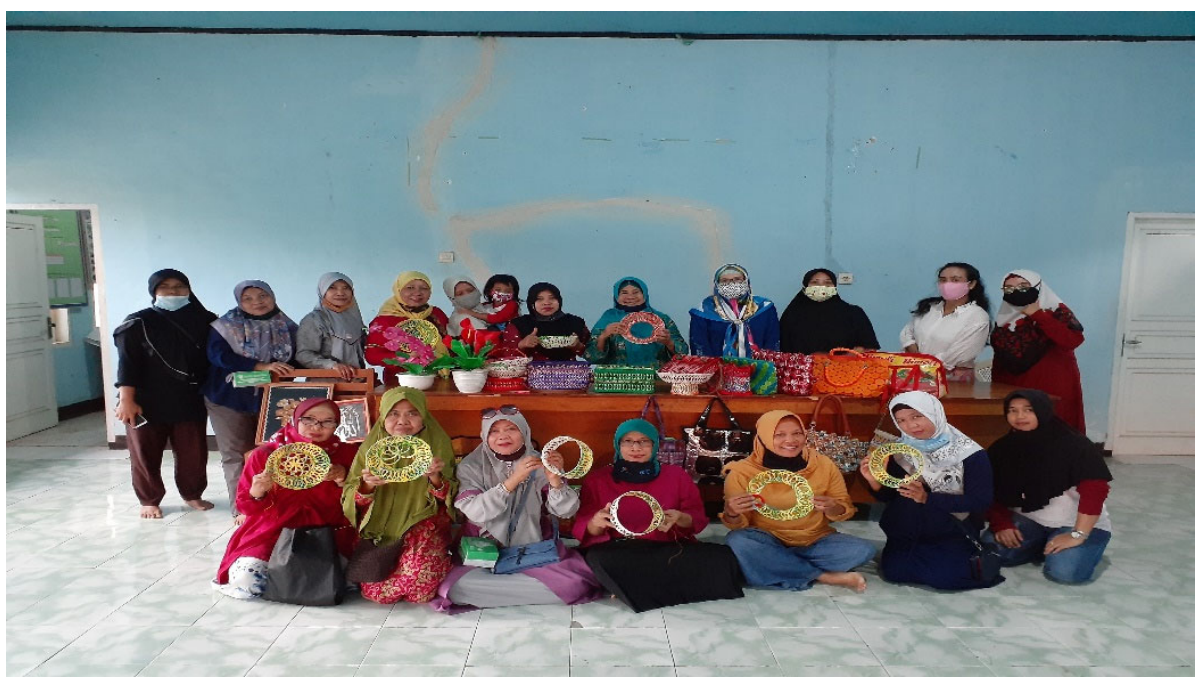

Foto: Para peserta pelatihan dan hasil karyanya

Berdasarkan pelaksanaan kegiatan pengabdian ini, dapat diidentifikasi hal-hal sebagai berikut : 
1. Umumnya para peserta pelatihan yakni ibu-ibu penggerak PKK desa Sandik sebelumnya sebagai peserta belum tahu cara pemanfaatan limbah plastik menjadi produk bernilai ekonomi.

2. Para peserta belum memanfaatkan limbah plastik yang sudah dikreasi sebagai salah satu sumber pendapatan keluarga.

3. Penggerak PKK desa sandik yang ikut sebagai peserta pelatihan setuju untuk menerapkan pengetahuan yang didapat dari pelatihan, untuk selanjutnya dijadikan sebagai usaha menambah pendapatan .

4. Peserta sepakat, setelah mampu secara tehnis dalam memanfaatkan sampah plastik menjadi produk bernilai ekonomi, untuk mencoba mengembangkannya ke arah bisnis dengan mengaplikasikan ilmu pengetahuan manajemen usaha.

Faktor penghambat dalam pelaksanaan pelatihan hanya terletak pada terbatasnya waktu yang dikarenakan terlambatnya ibu-ibu peserta pelatihan datang ke lokasi pelatihan, sehingga waktu yang tersedia menjadi berkurang. Waktu pelatihan terasa kurang baik bagi pelatih maupun peserta.

Faktor Pendukung, sehingga dapat terlaksanya pelatihan dengan lancar adalah:

a. Adanya dukungan dari pihak pemerintah desa khususnya dari bapak Sekertaris Desa dan staf Desa Sandik Kecamatan Batu Layar Kabupaten Lombok Barat.

b. Motivasi yang tinggi dari Ketua, sekertaris dan angota Tim Penggerak PKK Desa, Desa Sandik selaku peserta pelatihan, dan ini sesuai dengan kebutuhannya dalam rangka pengembangan masyarakat desa

c. Tersedianya Aula Kantor Desa sebagai tempat dilaksanakannya kegiatan pengabdian.

d. Adanya dukungan dana DIPA BLU Universitas Mataram tahun 2020.

e. Kekompakan Tim pengabdian dari Fakultas Ekonomi dan Bisnis Unram dalam mempersiapkan kegiatan pengabdian dari awal samapi selesai. 


\section{Jurnal ABDIMAS INDEPENDEN}

Vol. 2, No. 2, November 2021

Pelatihan ini dipandang berhasil, karena dari hasil pelaksanaan menunjukkan :

1. Tingkat kehadiran peserta yang tinggi, yakni 16 orang ( $106 \%$ ) dari 15 orang yang direncanakan (karena suasana covid-19 jadi peserta dibatasi), dan mengikuti pelatihan dari awal sampai selesai.

2. Keaktipan peserta saat pelatihan cukup tinggi terlihat dari kegiatan diskusi, dan tanya-jawab.

3. Terdapat peserta yang mampu membuat produk diakhir pelatihan, walaupun tidak semua .

4. Adanya kesediaan dari para peserta untuk menularkannya kepada ibuibu yang lain yang menjadi warga Desa Sandik.

Kegiatan pengabdian ini akan berkelanjutan, karena; (1) Adanya latihan berantai (estafet) yang akan direncanakan oleh ketua dan sekretaris PKK desa, (2) Disamping itu, diharapkan tidak hanya sebatas penanganan sampah plastik menjadi produk saja, namun menjadi produk ekonomis dalam artian dapat dijadikan sebagai sumber pendapatan, disamping adanya lingkungan yang bersih, (3) adanya dukungan dari ibu ketua PKK desa untuk mengembangkan kegiatan ini lebih lanjut dengan memberikan pelatihan yang sama pada ibu-ibu yang lain, sehingga dapat memperbaiki ekonomi keluarga di Desa Sandik Kecamatan Batu Layar. Untuk masalah ini, sekertaris PKK Desa Sandik Bahkan sudah menghubungi tutor yang dibawa oleh Tim FEB untuk dapat memberikan pelatihan kembali pada ibu-ibu di desa Sandik.

\section{KESIMPULAN DAN SARAN}

\section{Kesimpulan}

Berdasarkan hasil pelaksanaan kegiatan pemberdayaan ibu-ibu tim Penggerak PKK Desa di Desa Sandik yang dilatih secara tehnis untuk memanfaatkan sampah non-organik dan pengelolaan usaha, dapat ditarik beberapa kesimpulan: 
1. Pelaksanaan Pengabdian Kepada Masyarakat berupa Pemberdayaan Penggerak PKK melalui Pengembangan Kerajinan Sampah Non-Organik di Desa Sandik Kecamatan Batu Layar Lombok Barat, berjalan dengan lancar sesuai rencana

2. Pelaksanaan pelatihan ini dapat dikatakan berhasil karena dari hasil evaluasi yang diakukan menunjukkan :

a) Kehadiran peserta sebanyak 16 orang (106\%) dari 15 orang yang direncanakan, dan semua peserta antusias mengikuti acara dari awal sampai selesai.

b) Keaktifan peserta saat pelatihn cukup tinggi, terlihat dari tanya jawab dan keseriusan para peserta.

c) Peserta Cukup Mampu mempraktekkan materi yang diberikan.

d) Adanya dukungan dari desa yang dibuktikan dengan disiapkannya ruangan/tempat pelatihan.

e) Para peserta menjadi lebih mengetahui mana sampah yang termasuk sampah organik dan mana yang non-organik.

f) Bertambahnya pengetahuan peserta tentang adanya beberapa jenis sampah non-organik yang mereka hasilkan setiap harinya dapat dimanfaatkan dan diubah/diolah menjadi sesuatu yang bermanfaat dan mempunyai nailai ekonomis yang dapat mereka jadikan sebagai sumber tambahan pendapatan keluarga.

Saran

Berdasarkan hasil pengabdian, ada beberapa saran yang perlu diperhatikan:

a) Menindaklanjuti pengembangan produk dengan bahan baku plastik, seperti: inke (piring), bunga, hiasan dinding, peci, kotak tisu, tempat air minum gelasan, tas, dan lain-lain.

b) Membentuk bank sampah di setiap rumah sebelum dikumpulkan pada bank sampah kelompok, sebagai sumber bahan baku produksi 
c) Menjalin kerjasama dengan berbagai pihak seperti; Diskoperindakkop Lombok Barat, LSM yang bergerak dibidang Lingkungan hidup, Tutor $\mathrm{Hj}$ Nurnia, dan lainnya.

d) Perlu memikirkan untuk melakukan kegiatan ini kearah bisnis, sehingga kata-kata upaya menambah pendapatan masyarakat dapat diwujudkan.

e) Perlu membentuk kelompok sebagai sarana bersama dalam mengembangkan aktivitas bisnis dalam bidang hasil pemanfaatan sampah non-organik kedepan.

\section{UCAPAN TERIMA KASIH}

Terlaksananya kegiatan Pengabdian Kepada Masyarakat ini, tidak terlepas dari peran berbagai pihak. Oleh karena itu pada kesempatan ini kami (Tim pengabdian) mengucapkan terima Kasih dan penghargaan kepada:

1. Ketua LPPM Unram yang telah menyediakan dana pengabdian DIPA BLU UnramTh 2019.

2. Kepala Desa dan Sekertaris Desa Sandik beserta staff yang telah mendukung kegiatan pengabdian dengan menyiapkan ruangan (AULA kantor desa) dan fasilitas pendukung lain yang diperlukan.

3. Tim Penggerak PKK Desa di Desa Sandik yang telah bersedia untuk memotivasi dan mengikuti kegiatan pelatihan.

\section{DAFTAR PUSTAKA}

Anonim, Undang-Undang No.23 Tahun 1997 tentang Pengelolaan Lingkungan Hidup. , Undang-UndangNo. 18 Tahun 2008 tentang Pengelolaan Sampah. 
, 2019, Potensi Desa Sandik Kecamatan batu layar Kabupaten Lombok Barat

Sutoyo, Bagong.2013. Fenomena gerakan mengolah sampah.Jakarta : Pusat Komunikasi publik kementrian pekerjaan umum.

Ismiwati, et all, Pemberdayaan Wanita Nelayan Melalui Pemanfaatan Sampah Non-organik Sebagai Upaya Menambah Pendapatan Masyarakat di Desa Kuranji Dalang Kecamatan Labuapi Kabupaten Lombok Barat. LPPM Universitas Mataram, 2019. 